\title{
Dietary intake of lycopene by the Belgian adult population
}

\author{
Stefanie Vandevijvere ${ }^{1, *}$, Tatiana Cucu ${ }^{2}$, Christine Vinkx $^{3}$, Kevin Huvaere ${ }^{1}$, \\ Inge Huybrechts ${ }^{4}$ and Joris Van Loco' \\ 'Department of Public Health and Surveillance, Scientific Institute of Public Health, J. Wytsmanstraat 14, B-1050 \\ Brussels, Belgium: ${ }^{2}$ Department of Food, Medicines and Consumer Safety, Scientific Institute of Public Health, \\ Brussels, Belgium: ${ }^{3}$ Federal Public Service of Health, Food Chain Safety and Environment, Brussels, Belgium: \\ ${ }^{4}$ Department of Public Health, Ghent University, Ghent, Belgium
}

Submitted 22 June 2012: Final revision received 22 November 2012: Accepted 25 November 2012: First published online 4 January 2013

\begin{abstract}
Objective: Lycopene is a potent antioxidant, and it has been suggested that intake of tomatoes and tomato products containing lycopene is associated with a decreased risk of various chronic diseases. The aim of the present study was to evaluate the distribution of dietary lycopene intake in the Belgian population and to determine the most important contributors to lycopene intake.

Design: Cross-sectional study.

Setting: National food consumption data from the Belgian Food Consumption Survey (BFCS) 2004 were used for the intake assessment. Determination of the lycopene content in foods was performed with HPLC-UV. Individual food consumption data were multiplied by the actual mean concentrations of lycopene per food. Subjects: Individuals ( $n$ 3083) aged 15 years and older participated in the study and provided two $24 \mathrm{~h}$ recalls.

Results: The mean lycopene intake among Belgian adults was $4 \cdot 1$ (sD $2 \cdot 3) \mathrm{mg} / \mathrm{d}$ or 0.059 (sD 0.033$) \mathrm{mg} / \mathrm{kg}$ body weight per d. Lycopene intake among men $(4.6$ (SD $2 \cdot 6) \mathrm{mg} / \mathrm{d}$ ) was higher than among women $(3.6$ (SD $2 \cdot 1) \mathrm{mg} / \mathrm{d}$ ), and was higher in the younger compared with the older age groups. Cis-lycopene intake represented about one-third of the total lycopene intake. Tomatoes and tomato products (43\%) and sauces and ready-to-eat meals containing tomato sauces (41\%) were the main contributors to lycopene intake in Belgium.

Conclusions: The lycopene intake of the Belgian adult population was comparable to intakes reported in neighbouring countries and was below the acceptable daily intake.
\end{abstract}

Numerous epidemiological studies have shown an inverse association between fruit and vegetable consumption and chronic diseases, including different types of cancer and $\mathrm{CVD}^{(1)}$. Therefore, the interest in the health benefits of fruit and vegetable consumption has increased during the last decades. Moreover, the interest in the types, concentrations and modes of action of the different components from fruits and vegetables responsible for the beneficial health effects has increased as well.

Carotenoids are natural fat-soluble pigments from plants such as orange fruits, red or yellow fruits and vegetables, and some dark green vegetables. The key property of carotenoids is their capacity for quenching singlet oxygen and free radicals depending on the number of conjugated double bonds ${ }^{(2)}$. Lycopene is an acyclic isomer of $\beta$-carotene containing linearly arranged eleven conjugated and two unconjugated double bonds ${ }^{(3)}$. The unique chemical properties of lycopene derive from its structure, which makes it extremely hydrophobic and soluble in tissues, milk and organic solvents ${ }^{(2)}$.
Lycopene from natural plant sources exists predominantly in an all-trans configuration, the most thermodynamically stable form with eleven carbon-carbon double bonds ${ }^{(4)}$. Of these eleven double bonds, seven can be isomerized from the trans form to the mono- or poly-cis forms under the influence of excess heat, light or certain chemical reactions. Although the predominant form of lycopene in foods is all-trans, human blood and tissues contain mainly cis-isomers. The bioavailability of cis-lycopene was found to be higher than that of trans-lycopene and cis-lycopene is preferentially absorbed ${ }^{(5)}$.

Since lycopene lacks the $\beta$-ionone ring structure, it cannot form vitamin A. Its biological effects in man have therefore been attributed to mechanisms other than vitamin A including antioxidant effects and immune response modulators ${ }^{(2)}$. Lycopene is one of the most potent antioxidants, with a singlet-oxygen-quenching ability twice as high as that of $\beta$-carotene and ten times higher than that of $\alpha$-tocopherol ${ }^{(6)}$. It has been suggested that dietary intake of tomatoes and tomato products 
containing lycopene might be associated with a decreased risk of chronic diseases such as cancer and CVD ${ }^{(7-11)}$. However, a large-scale study did not find an association between lycopene intake and prostate cancer risk ${ }^{(12)}$. In addition, a systematic review concluded that, given the limited number of randomized controlled trials published, it is not possible to support or refute the use of lycopene for the prevention or treatment of prostate cancer ${ }^{(13)}$. It has also been suggested that nutrients with redox modulator properties, such as lycopene, might have beneficial effects on the risk of other chronic diseases such as diabetes, neurodegenerative diseases and ocular disorders, as well as on asthma and viral infections ${ }^{(14)}$.

Dietary lycopene is obtained from a limited list of foods only, in contrast to the other major carotenoids. The principal source of dietary lycopene is tomato in most people's diets. It is worth mentioning that the lycopene content varies substantially in different varieties of tomato, in different climates and with the use of different agricultural practices. Besides tomatoes and tomato-derived products (tomato juice, sauces, paste, etc.), watermelon, pink grapefruit, guava and papaya have been shown to be important sources of lycopene ${ }^{(14,15)}$. Although comparative bioavailability values for lycopene from different tomato products are unknown, lycopene from processed tomato products appears to be more bioavailable than that from raw tomatoes ${ }^{(5,16)}$. The release of lycopene from the food matrix due to processing has been reported to enhance lycopene bioavailability. Moreover, lycopene is a fat-soluble compound, which implies that absorption is improved when fat is present, and it should therefore be ingested within a mixed meal $^{(17)}$. It has also been reported that the bioavailability of lycopene is affected by the dosage and the presence of other carotenoids, among which $\beta$-carotene. It was shown that the bioavailability of lycopene was significantly higher when it was ingested along with $\beta$-carotene than when ingested separately ${ }^{(18)}$.

Results from dietary surveys show mean usual intakes of lycopene from natural dietary sources in different populations between 0.5 and $5 \mathrm{mg} / \mathrm{d}$, with high intakes up to about $8 \mathrm{mg} / \mathrm{d}^{(19)}$. High consumption of fruits and vegetables, especially tomato products, may result in occasional intakes of $20 \mathrm{mg}$ lycopene/d or more ${ }^{(3)}$. The European Food Safety Authority's Panel on Food Additives, Flavourings, Processing Aids and Materials in Contact with Foods established an Acceptable Daily Intake (ADI) for lycopene in 2008 of $0.5 \mathrm{mg} / \mathrm{kg}$ body weight (BW) per $\mathrm{d}^{(19)}$. This ADI value refers to lycopene from all sources, since lycopene is also reported to be used as a food colorant and ingredient in novel foods.

The aim of the present study was to assess the distribution of lycopene intake in the Belgian adult population and to determine which foods are the main contributors to the intake. Both total and cis-lycopene intakes were assessed.

\section{Materials and methods}

\section{Food consumption data}

Consumption data from the Belgian Food Consumption Survey (BFCS; dating from 2004) were used to perform the intake assessment. The target population of the BFCS comprised Belgian adults aged 15 years and older. Aims, design and methods of this survey can be found elsewhere ${ }^{(20)}$. The study was conducted according to the guidelines laid down in the Declaration of Helsinki and all procedures involving human subjects/patients were approved by the medical ethical committee of the Scientific Institute of Public Health. Written informed consent was obtained from all participants. The sample included 3245 individuals who were randomly selected from the National Register using a multistage stratified procedure. Information on dietary intake was collected by two non-consecutive $24 \mathrm{~h}$ recalls. During the $24 \mathrm{~h}$ recall interviews, the respondent reported the quantity of all foods and beverages consumed during the preceding day. The survey covered one full year and the response rate was on average $41 \%$.

\section{Food label survey}

According to the EU Directive 94/36/EC on colours for use in foods, lycopene (E160d) is allowed to be used in certain categories of foods such those as listed in Annex V part 2 of the Directive ${ }^{(21)}$. Therefore, a label survey was performed to investigate whether food products on the Belgian market contained lycopene added as colour. The label survey was performed based on the presumption that labelling of food additives is mandatory. The labels of foods from five major Belgian supermarkets were screened for lycopene or E160d between May and August 2011.

\section{Lycopene concentration of foods}

Food samples were purchased in supermarkets and local stores. The ingredient lists of purchased foods were checked and all foods that had products containing lycopene among the ingredients listed were analysed.

A total of 322 food samples were selected, which were finely ground and homogenized before analysis. For the determination of total and cis-lycopene content in foods, an HPLC-UV method was used as previously described ${ }^{(22)}$.

\section{Intake assessment}

Both $24 \mathrm{~h}$ recalls, which were carried out using the EPICSOFT software ${ }^{(23)}$, were completed by 3083 participants; 1546 men and 1537 women (hence 6166 recalls).The individual intake of lycopene from a certain food product was calculated using the equation:

$$
Y_{i}=\left(c_{i} \times x_{i}\right) / B W_{i},
$$

where $Y_{i}$ is the intake of the lycopene by individual $i$ from a particular food on an interview day ( $\mathrm{mg} / \mathrm{kg} \mathrm{BW}$ per $\mathrm{d})$; $c_{i}$ is the concentration of the lycopene in the food $(\mathrm{mg} / \mathrm{kg})$; 
$x_{i}$ is the consumption of a certain food by individual $i(\mathrm{~kg})$; and $B W_{i}$ is the self-reported BW of individual $i(\mathrm{~kg})$. To estimate the total intake of lycopene/food group per $\mathrm{d}$, individual daily intakes of lycopene from different foods were added up. The arithmetic means of the levels of lycopene in tomatoes, tomato products and foods containing lycopene derived from fruits and vegetables were calculated.

The usual intake distribution for lycopene was estimated with the Nusser method ${ }^{(24)}$ using the C-SIDE software ${ }^{(25)}$. This statistical procedure adjusts for within-person or day-to-day variability. The usual intake distribution was weighted and adjusted for the age and sex distribution of the Belgian population and adjusted for day of the week and season.

In order to assess the contribution of several foods to lycopene intake, foods were classified into the following groups: tomatoes and tomato products (raw tomatoes, tomato concentrate, tomato paste, chopped/canned tomatoes); fruits and fruit products (watermelon, papaya, grapefruit, fruit salads); dairy products (cheeses with herbs, yoghurts with fruits); cereals and cereal products (chips, salted biscuits, breakfast cereals, raw pasta); biscuits; meat salads and products (meat salads, tête pressée and sausages); fish salads and products (fish salads and fish products in tomato sauce); butter with herbs; confectionery (jam, candies containing fruits); tomato and fruit juices; soups; and a group of sauces (such as ketchup, pesto rosso, pasta sauces, other sauces, tapenades) together with ready-to-eat meals containing tomatoes (such as pasta, pizza, lasagne).
The population proportion formula was used to determine the percentage contribution of each food group to the intake of lycopene ${ }^{(26)}$, which includes summing the amount of the component provided by the food for all individuals and dividing by the total intake of that component from all foods for the entire study population.

\section{Results}

The label study performed on the Belgian market (represented by the five main supermarkets) indicated that no lycopene as either a food colour or a novel food ingredient was used in foods. Taking into account this observation, only the intake of lycopene from natural sources was further considered in the present study.

Table 1 shows the cis-and total lycopene concentration levels in different foods. As expected, the foods containing the highest lycopene level were tomatoes and tomato-derived products such as juices, paste, concentrate and sauces. However, high variability in the lycopene content was observed for all analysed food products. In the case of fresh tomatoes for example, total lycopene content ranged from 33.3 to $103.7 \mathrm{mg} / \mathrm{kg}$. The concentration of cis-lycopene varied between the food groups as well. As expected, highly processed foods (sauces, soups, ready-to-eat meals) contained the highest amounts of cis-lycopene compared with non-processed foods (raw tomatoes and fruits).

The mean total lycopene intake of the general population ( $n$ 3083) was $4 \cdot 1(\mathrm{sD} 2 \cdot 3) \mathrm{mg} / \mathrm{d}$ and $8.5 \mathrm{mg} / \mathrm{d}$ at the

Table 1 Cis- and total lycopene contents of some common foods on the Belgian market

\begin{tabular}{|c|c|c|c|c|c|c|c|}
\hline & \multirow{2}{*}{$\begin{array}{c}\text { No. of samples } \\
\text { analysed }\end{array}$} & \multicolumn{3}{|c|}{$\begin{array}{l}\text { Cis-lycopene } \\
\text { (mg/kg product) }\end{array}$} & \multicolumn{3}{|c|}{$\begin{array}{l}\text { Total lycopene } \\
\text { (mg/kg product) }\end{array}$} \\
\hline & & Mean & Min & Max & Mean & Min & Max \\
\hline Raw tomatoes & 5 & $4 \cdot 0$ & $1 \cdot 9$ & $5 \cdot 1$ & $69 \cdot 0$ & $33 \cdot 3$ & $103 \cdot 7$ \\
\hline Tomato concentrate & 2 & $17 \cdot 8$ & $17 \cdot 3$ & $18 \cdot 3$ & $328 \cdot 3$ & $298 \cdot 1$ & $358 \cdot 4$ \\
\hline Tomato double concentrate & 5 & $27 \cdot 6$ & $27 \cdot 0$ & $30 \cdot 6$ & $512 \cdot 0$ & $455 \cdot 7$ & $604 \cdot 3$ \\
\hline Canned tomatoes, whole or chopped & 19 & $6 \cdot 9$ & $5 \cdot 8$ & $8 \cdot 7$ & $121 \cdot 8$ & $70 \cdot 4$ & $218 \cdot 3$ \\
\hline Tomato juice & 5 & $3 \cdot 5$ & $2 \cdot 2$ & $5 \cdot 7$ & $72 \cdot 2$ & $60 \cdot 6$ & $82 \cdot 5$ \\
\hline Sun-dried tomatoes & 2 & $5 \cdot 5$ & $4 \cdot 9$ & $6 \cdot 0$ & $86 \cdot 5$ & $79 \cdot 2$ & $93 \cdot 8$ \\
\hline Pasta with various tomato sauces & 21 & $5 \cdot 5$ & $1 \cdot 2$ & $20 \cdot 5$ & $23 \cdot 5$ & $11 \cdot 2$ & $37 \cdot 1$ \\
\hline Pizza & 6 & $3 \cdot 2$ & $0 \cdot 7$ & $7 \cdot 6$ & $22 \cdot 9$ & $11 \cdot 0$ & $41 \cdot 3$ \\
\hline Ketchup & 4 & $4 \cdot 3$ & $1 \cdot 0$ & $7 \cdot 1$ & $81 \cdot 4$ & $28 \cdot 8$ & $148 \cdot 5$ \\
\hline Pesto rosso & 4 & $10 \cdot 2$ & $8 \cdot 0$ & $16 \cdot 0$ & $68 \cdot 2$ & $41 \cdot 8$ & $121 \cdot 2$ \\
\hline Pasta sauces & 18 & $13 \cdot 2$ & $3 \cdot 8$ & $18 \cdot 9$ & $68 \cdot 0$ & 28.9 & $120 \cdot 0$ \\
\hline Other sauces & 14 & $4 \cdot 2$ & 1.5 & $5 \cdot 0$ & 33.9 & $6 \cdot 9$ & $80 \cdot 8$ \\
\hline Soup & 16 & $6 \cdot 5$ & 0.3 & $14 \cdot 5$ & $27 \cdot 4$ & $1 \cdot 3$ & $77 \cdot 9$ \\
\hline Chips and popped snacks* & 8 & $\mathrm{n} / \mathrm{d}$ & $\mathrm{n} / \mathrm{d}$ & $\mathrm{n} / \mathrm{d}$ & 0.8 & $0 \cdot 2$ & $1 \cdot 8$ \\
\hline Cheeses $^{*}$ & 7 & 0.9 & $0 \cdot 2$ & $1 \cdot 3$ & $6 \cdot 0$ & $1 \cdot 0$ & $17 \cdot 5$ \\
\hline Candies* & 6 & 0.1 & $0 \cdot 3$ & 0.4 & $1 \cdot 2$ & 0.6 & 2.9 \\
\hline Water melon & 2 & $2 \cdot 9$ & $1 \cdot 5$ & $4 \cdot 3$ & $134 \cdot 7$ & $98 \cdot 1$ & $171 \cdot 3$ \\
\hline Papaya & 3 & 0.6 & 0.6 & 0.7 & $17 \cdot 1$ & $5 \cdot 3$ & $33 \cdot 2$ \\
\hline Grapefruit & 1 & $0 \cdot 4$ & - & - & $28 \cdot 2$ & - & - \\
\hline Fruit salads & 6 & 0.2 & $0 \cdot 0$ & $0 \cdot 4$ & $7 \cdot 0$ & $1 \cdot 3$ & $19 \cdot 5$ \\
\hline Fish products and salads & 10 & $3 \cdot 9$ & $1 \cdot 0$ & $10 \cdot 6$ & $25 \cdot 2$ & $2 \cdot 2$ & $44 \cdot 4$ \\
\hline Meat salads, merguez, tête pressée & 9 & $2 \cdot 3$ & 0.6 & $6 \cdot 0$ & $8 \cdot 3$ & $0 \cdot \overline{1}$ & $28 \cdot 7$ \\
\hline
\end{tabular}

$\mathrm{n} / \mathrm{d}$, not detected.

*Only samples with 'tomato extract' or 'tomato powder' mentioned on the label were considered. 
95th percentile (Table 2). The total lycopene intake of men was significantly higher than that of women $(4.6(\mathrm{sD} 2 \cdot 6) \mathrm{mg} / \mathrm{d}$ on average $v .3 \cdot 6(\mathrm{sD} 2 \cdot 1) \mathrm{mg} / \mathrm{d}$ on average respectively; $P<0 \cdot 001$ ). For men the intake at the 95 th percentile was $9.5 \mathrm{mg} / \mathrm{d}$ while for women the lycopene intake at the 95 th percentile was $7.6 \mathrm{mg} / \mathrm{d}$. The higher intake among men compared with women was mainly due to the higher lycopene intake via sauces and ready-to-eat meals among men $(1.75 \mathrm{mg} / \mathrm{d})$ compared with women $(1 \cdot 17 \mathrm{mg} / \mathrm{d})$. For both men and women, the total lycopene intake was lower in the older than among the younger age groups.

The mean total lycopene intake was $0.059 \mathrm{mg} / \mathrm{kg} \mathrm{BW}$ per $\mathrm{d}$. At none of the percentiles was the ADI of $0.5 \mathrm{mg} / \mathrm{kg}$ BW per d exceeded. Even at the 99th percentile, the total lycopene intake was only $0 \cdot 165 \mathrm{mg} / \mathrm{kg}$ BW per d which is about $33 \%$ of the established ADI value (Table 2 and Fig. 1). The intake of cis-lycopene among the Belgian population was $0 \cdot 019$ (sD $0 \cdot 011) \mathrm{mg} / \mathrm{kg} \mathrm{BW}$ per $\mathrm{d}$, which represents about $30 \%$ of the total lycopene intake. Similar to total lycopene, cis-lycopene intake was higher among men than women, although to a slightly lower extent (Table 3).

Table 4 shows the food sources contributing to lycopene intake for the Belgian adults. From Table 4 it is obvious that the main contributors to lycopene intake in the Belgian population were the group of tomatoes and tomato products ( $43 \%$ ), together with the group of sauces and ready-to-eat meals ( $41 \%)$. These two food groups accounted for about $85 \%$ of the total lycopene intake.

\section{Discussion}

The results of the present study show that the mean intake of lycopene among Belgian adults was $0.059 \mathrm{mg} / \mathrm{kg}$ BW per $\mathrm{d}$. The lycopene intake of the Belgian population was well below the ADI which was set by the European Food Safety Authority. Intake of cis-lycopene, which may be formed upon processing of foods involving heat and which is more bioavailable than trans-lycopene, represented about one-third of total lycopene intake. When comparing the lycopene intake of the Belgian adult population with that of populations in other countries, it was observed that the intake in Belgium is comparable to the intake of adults in the Netherlands, France, Republic of Ireland and Australia (Table 5) ${ }^{(27)}$. Reported lycopene intakes in the USA and Canada were much higher due to the difference in dietary assessment methods used. It was previously shown that mean dietary intakes of lycopene estimated with FFQ (as in the case of intake assessment for the USA and Canada) may be higher than those

Table 2 Estimated total lycopene intake from natural sources (in mg/kg BW per d and mg/d) of the Belgian adult population; Belgian Food Consumption Survey (BFCS), 2004

\begin{tabular}{|c|c|c|c|c|c|c|c|c|}
\hline & $n$ & Mean & SD & P50 & P95 & P97.5 & P99 & $\%$ ADI \\
\hline & \multicolumn{8}{|c|}{ Results in $\mathrm{mg} / \mathrm{kg} \mathrm{BW}$ per $\mathrm{d}$} \\
\hline $\begin{array}{l}\text { Total population } \\
\text { Men }\end{array}$ & 3083 & 0.059 & 0.033 & 0.052 & $0 \cdot 123$ & $0 \cdot 142$ & $0 \cdot 165$ & $11 \cdot 8$ \\
\hline Total population & 1546 & 0.061 & 0.036 & 0.054 & 0.129 & 0.149 & 0.176 & $12 \cdot 2$ \\
\hline $15-18$ years & 381 & 0.066 & 0.027 & 0.062 & $0 \cdot 115$ & $0 \cdot 128$ & $0 \cdot 143$ & $13 \cdot 2$ \\
\hline $19-59$ years & 394 & 0.071 & 0.031 & 0.068 & $0 \cdot 128$ & $0 \cdot 142$ & $0 \cdot 160$ & $14 \cdot 2$ \\
\hline $60-74$ years & 399 & 0.033 & 0.015 & 0.032 & 0.058 & 0.065 & 0.073 & $6 \cdot 6$ \\
\hline$>74$ years & 372 & $0 \cdot 030$ & 0.020 & 0.026 & 0.068 & 0.081 & 0.098 & $6 \cdot 0$ \\
\hline \multicolumn{9}{|l|}{ Women } \\
\hline Total population & 1537 & 0.057 & 0.033 & 0.050 & $0 \cdot 122$ & $0 \cdot 142$ & 0.167 & $11 \cdot 4$ \\
\hline $15-18$ years & 379 & 0.074 & 0.029 & 0.071 & $0 \cdot 128$ & $0 \cdot 141$ & 0.159 & $14 \cdot 8$ \\
\hline $19-59$ years & 436 & 0.065 & 0.036 & 0.057 & 0.136 & $0 \cdot 157$ & 0.183 & $13 \cdot 0$ \\
\hline $60-74$ years & 390 & 0.042 & 0.020 & 0.039 & 0.078 & 0.087 & 0.099 & $8 \cdot 4$ \\
\hline$>74$ years & 332 & $0 \cdot 026$ & $0 \cdot 016$ & 0.022 & 0.059 & 0.070 & $0 \cdot 086$ & $5 \cdot 2$ \\
\hline & \multicolumn{8}{|c|}{ Results in mg/d } \\
\hline Total population & 3083 & $4 \cdot 1$ & $2 \cdot 3$ & $3 \cdot 6$ & $8 \cdot 5$ & $9 \cdot 8$ & $11 \cdot 4$ & - \\
\hline Men & & & & & & & & \\
\hline Total population & 1546 & $4 \cdot 6$ & $2 \cdot 6$ & $4 \cdot 1$ & $9 \cdot 5$ & $10 \cdot 9$ & $12 \cdot 7$ & - \\
\hline $15-18$ years & 381 & $4 \cdot 3$ & $1 \cdot 8$ & $4 \cdot 1$ & $7 \cdot 6$ & $8 \cdot 5$ & $9 \cdot 5$ & - \\
\hline $19-59$ years & 394 & $5 \cdot 4$ & $2 \cdot 4$ & $5 \cdot 2$ & $9 \cdot 7$ & $10 \cdot 8$ & $12 \cdot 2$ & - \\
\hline $60-74$ years & 399 & $2 \cdot 6$ & $1 \cdot 1$ & $2 \cdot 5$ & $4 \cdot 4$ & $4 \cdot 9$ & $5 \cdot 5$ & - \\
\hline$>74$ years & 372 & $2 \cdot 2$ & $1 \cdot 4$ & $1 \cdot 9$ & $5 \cdot 0$ & $5 \cdot 9$ & $7 \cdot 2$ & - \\
\hline \multicolumn{9}{|l|}{ Women } \\
\hline Total population & 1537 & $3 \cdot 6$ & $2 \cdot 1$ & $3 \cdot 1$ & $7 \cdot 6$ & $8 \cdot 8$ & $10 \cdot 3$ & - \\
\hline $15-18$ years & 379 & $4 \cdot 3$ & $1 \cdot 6$ & $4 \cdot 1$ & $7 \cdot 1$ & $7 \cdot 9$ & $8 \cdot 8$ & - \\
\hline $19-59$ years & 436 & $4 \cdot 1$ & $2 \cdot 1$ & $3 \cdot 7$ & $8 \cdot 1$ & $9 \cdot 2$ & $10 \cdot 5$ & - \\
\hline $60-74$ years & 390 & $2 \cdot 8$ & $1 \cdot 3$ & $2 \cdot 6$ & $5 \cdot 1$ & $5 \cdot 7$ & $6 \cdot 5$ & - \\
\hline$>74$ years & 332 & $1 \cdot 7$ & $1 \cdot 1$ & $1 \cdot 4$ & $3 \cdot 8$ & $4 \cdot 5$ & $5 \cdot 6$ & - \\
\hline
\end{tabular}

BW, body weight; $\mathrm{P}$, percentile; ADI, acceptable daily intake. 


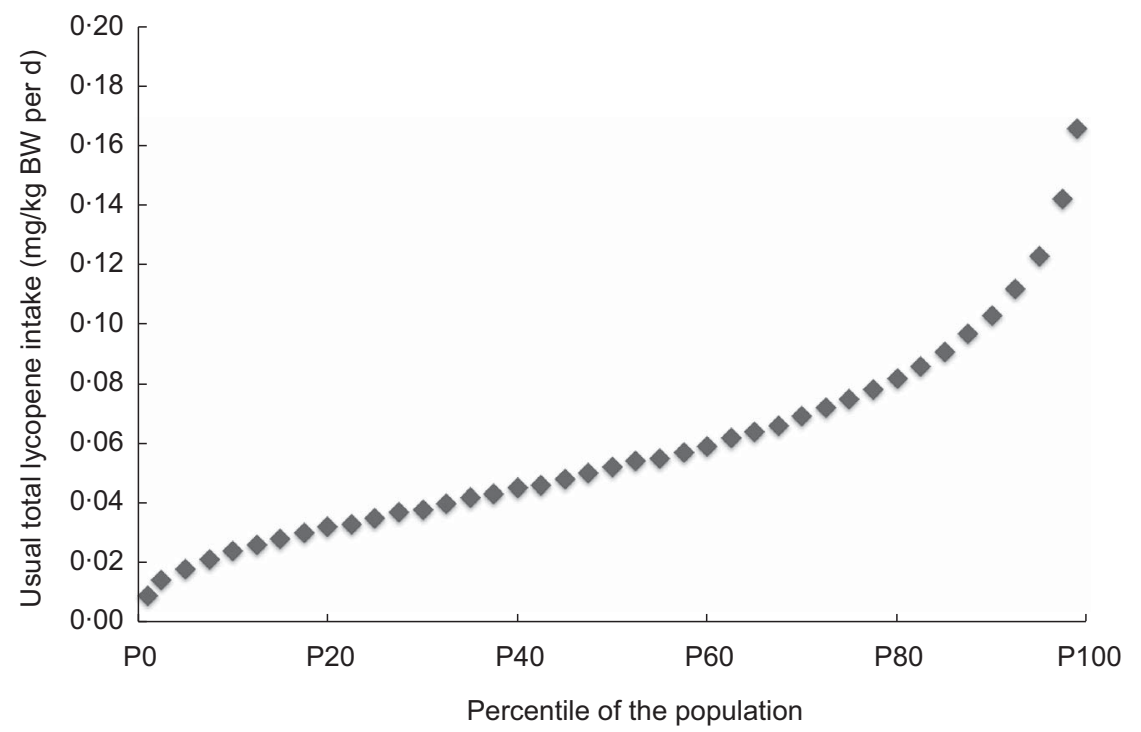

Fig. 1 Estimated usual daily intake of total lycopene from natural sources ( $\mathrm{mg} / \mathrm{kg}$ body weight (BW) per d) of the Belgian adult population ( $n$ 3083, all days, all population); Belgian Food Consumption Survey (BFCS), 2004

Table 3 Estimated cis-lycopene intake from natural sources (in $\mathrm{mg} / \mathrm{kg} \mathrm{BW}$ per $\mathrm{d}$ and in $\mathrm{mg} / \mathrm{d}$ ) of the Belgian adult population; Belgian Food Consumption Survey (BFCS), 2004

\begin{tabular}{|c|c|c|c|c|c|c|c|c|}
\hline & $n$ & Mean & SD & $\mathrm{P} 50$ & P95 & $\mathrm{P} 97 \cdot 5$ & P99 & $\% \mathrm{ADI}$ \\
\hline & \multicolumn{8}{|c|}{ Results in $\mathrm{mg} / \mathrm{kg} \mathrm{BW}$ per $\mathrm{d}$} \\
\hline $\begin{array}{l}\text { Total population } \\
\text { Men }\end{array}$ & 3083 & 0.019 & 0.011 & 0.017 & 0.041 & 0.046 & 0.053 & $3 \cdot 8$ \\
\hline Total population & 1546 & 0.020 & $0 \cdot 012$ & 0.018 & 0.042 & 0.048 & 0.055 & $4 \cdot 0$ \\
\hline $15-18$ years & 381 & 0.020 & 0.010 & 0.018 & 0.040 & 0.045 & 0.051 & $4 \cdot 0$ \\
\hline $19-59$ years & 394 & 0.020 & 0.011 & 0.019 & 0.041 & 0.046 & 0.053 & $4 \cdot 0$ \\
\hline $60-74$ years & 399 & 0.017 & 0.010 & 0.015 & 0.036 & 0.040 & 0.045 & $3 \cdot 4$ \\
\hline$>74$ years & 372 & 0.020 & $0 \cdot 011$ & 0.020 & 0.038 & 0.042 & 0.048 & $4 \cdot 0$ \\
\hline \multicolumn{9}{|l|}{ Women } \\
\hline Total population & 1537 & 0.019 & 0.011 & 0.017 & $0 \cdot 040$ & 0.045 & 0.052 & $3 \cdot 8$ \\
\hline $15-18$ years & 379 & 0.019 & $0 \cdot 010$ & 0.018 & 0.039 & 0.044 & 0.051 & $3 \cdot 8$ \\
\hline $19-59$ years & 436 & 0.019 & 0.010 & 0.018 & 0.037 & 0.041 & 0.048 & $3 \cdot 8$ \\
\hline $60-74$ years & 390 & 0.018 & 0.010 & 0.017 & 0.036 & 0.040 & 0.045 & $3 \cdot 6$ \\
\hline \multirow[t]{2}{*}{$>74$ years } & 332 & 0.017 & $0 \cdot 012$ & 0.015 & 0.040 & 0.046 & 0.053 & $3 \cdot 4$ \\
\hline & & \multicolumn{7}{|c|}{ Results in $\mathrm{mg} / \mathrm{d}$} \\
\hline Total population & 3083 & $1 \cdot 33$ & 0.75 & $1 \cdot 2$ & $2 \cdot 8$ & $3 \cdot 1$ & $3 \cdot 5$ & - \\
\hline Men & & & & & & & & \\
\hline Total population & 1546 & $1 \cdot 49$ & 0.85 & $1 \cdot 3$ & $3 \cdot 1$ & 3.5 & $4 \cdot 0$ & - \\
\hline $15-18$ years & 381 & $1 \cdot 30$ & 0.64 & $1 \cdot 2$ & $2 \cdot 5$ & $2 \cdot 8$ & $3 \cdot 2$ & - \\
\hline $19-59$ years & 394 & $1 \cdot 55$ & 0.83 & $1 \cdot 4$ & $3 \cdot 1$ & 3.5 & $4 \cdot \overline{0}$ & - \\
\hline $60-74$ years & 399 & $1 \cdot 29$ & 0.74 & $1 \cdot 2$ & $2 \cdot 7$ & $3 \cdot 0$ & $3 \cdot 4$ & - \\
\hline$>74$ years & 372 & $1 \cdot 47$ & 0.74 & $1 \cdot 5$ & $2 \cdot 7$ & $3 \cdot 0$ & $3 \cdot 3$ & - \\
\hline \multicolumn{9}{|l|}{ Women } \\
\hline Total population & 1537 & $1 \cdot 17$ & 0.62 & $1 \cdot 1$ & $2 \cdot 3$ & $2 \cdot 6$ & $3 \cdot 0$ & - \\
\hline $15-18$ years & 379 & $1 \cdot 12$ & 0.59 & $1 \cdot 0$ & $2 \cdot 2$ & $2 \cdot 5$ & $2 \cdot 9$ & - \\
\hline $19-59$ years & 436 & $1 \cdot 17$ & 0.50 & $1 \cdot 1$ & $2 \cdot 1$ & $2 \cdot 3$ & $2 \cdot 6$ & - \\
\hline $60-74$ years & 390 & $1 \cdot 23$ & 0.58 & $1 \cdot 2$ & $2 \cdot 3$ & $2 \cdot 5$ & $2 \cdot 8$ & - \\
\hline$>74$ years & 332 & 1.09 & 0.77 & 0.9 & $2 \cdot 5$ & $2 \cdot 8$ & $3 \cdot 3$ & - \\
\hline
\end{tabular}

BW, body weight; $\mathrm{P}$, percentile; ADI, acceptable daily intake.

obtained with diet records ${ }^{(28)}$, both estimated records and weighed records ${ }^{(29,30)}$. The high intakes obtained with FFQ may result from a tendency of individuals to overestimate the consumption of vegetables and fruits when presented with a long list of food items. Differences between countries may also be linked to different dietary habits, the quality of the food composition database used and the variation of lycopene concentration within foods. 
Table 4 Contribution of several food groups to the mean intake of total lycopene from natural sources (mg/kg BW per d) of the Belgian population (all population, 6166 interviews, 3083 respondents); Belgian Food Consumption Survey (BFCS), 2004

\begin{tabular}{|c|c|c|c|c|c|}
\hline Food group & Mean & SD & P95 & $\begin{array}{l}\% \text { contribution to } \\
\text { mean total intake }\end{array}$ & $\begin{array}{c}\% \text { contribution to } \\
\text { the ADI }\end{array}$ \\
\hline Tomatoes and tomato products & 0.0230 & 0.0574 & $0 \cdot 1446$ & $42 \cdot 99$ & $4 \cdot 60$ \\
\hline Sauces and ready-to-eat meals & 0.0220 & 0.0613 & $0 \cdot 1584$ & $41 \cdot 12$ & $4 \cdot 40$ \\
\hline Tomato and fruit juices & 0.0027 & 0.0252 & $0 \cdot 0127$ & $5 \cdot 04$ & 0.54 \\
\hline Fruits and fruit products & 0.0025 & 0.0287 & 0.0011 & $4 \cdot 67$ & 0.50 \\
\hline Cereals and cereal products & 0.0009 & 0.0027 & 0.0066 & $1 \cdot 68$ & $0 \cdot 18$ \\
\hline Soups & 0.0008 & 0.0117 & 0.0000 & $1 \cdot 50$ & $0 \cdot 16$ \\
\hline Confectionery & 0.0006 & 0.0013 & 0.0030 & $1 \cdot 12$ & $0 \cdot 12$ \\
\hline Fish salads and products & 0.0004 & 0.0028 & 0.0000 & $0 \cdot 75$ & 0.08 \\
\hline Biscuits & 0.0003 & 0.0011 & 0.0022 & 0.56 & 0.06 \\
\hline Meat salads and products & 0.0003 & 0.0022 & 0.0000 & 0.53 & 0.06 \\
\hline Cheeses and yoghurt & 0.0002 & 0.0006 & 0.0009 & $0 \cdot 37$ & 0.04 \\
\hline Butter with herbs & 0.0000 & 0.0003 & 0.0000 & 0.00 & 0.00 \\
\hline Total & 0.0535 & 0.0914 & 0.2358 & - & - \\
\hline
\end{tabular}

BW, body weight; $P$, percentile; ADI, acceptable daily intake.

Table 5 Dietary lycopene intake from natural sources in selected countries ${ }^{(27)}$

\begin{tabular}{|c|c|c|c|c|c|c|}
\hline \multirow[b]{3}{*}{ Study } & \multicolumn{4}{|c|}{ Dietary intake $(\mu \mathrm{g} / \mathrm{d})$} & \multirow{2}{*}{\multicolumn{2}{|c|}{$\begin{array}{l}\text { Theoretical intake } \\
(\mathrm{mg} / \mathrm{kg} \mathrm{BW} \text { per } \mathrm{d})^{\star}\end{array}$}} \\
\hline & \multicolumn{2}{|c|}{ Males } & \multicolumn{2}{|c|}{ Females } & & \\
\hline & Mean & Range & Mean & Range & Males & Females \\
\hline Spain (n 70) & 1640 & $500-2640$ & 1640 & $500-2640$ & 0.023 & 0.023 \\
\hline France $(n 76)$ & 4750 & $2140-8310$ & 4750 & $2140-8310$ & 0.067 & 0.067 \\
\hline Republic of Ireland ( $n 76)$ & 4430 & 2730-71307 & 4430 & $2730-71307$ & 0.063 & 0.063 \\
\hline \multirow[t]{2}{*}{ Netherlands $(n 75)$} & 4860 & $2790-7530$ & 4860 & $2790-7530$ & 0.069 & 0.069 \\
\hline & Mean & SD & Mean & SD & & \\
\hline UK ( $n$ 42) & 1068 & 865 & - & - & 0.015 & 0.015 \\
\hline USA (n 307) & 10497 & 6177 & 10405 & 7278 & $0 \cdot 149$ & $0 \cdot 148$ \\
\hline Canada ( $n$ 1543) & 6363 & 11849 & 6363 & 11849 & 0.090 & 0.090 \\
\hline Australia ( $n$ 115) & 3813 & 9752 & 3813 & 9752 & 0.054 & 0.054 \\
\hline
\end{tabular}

BW, bodyweight.

${ }^{*}$ Considering that mean BW is $70 \mathrm{~kg}$.

The current study presents data on lycopene intake of the Belgian adult population. The total and cis-lycopene intakes were calculated based on their determination in a number of food products using an in-house analytical method $^{(22)}$. Therefore no variability regarding differences in analytical method influenced the results for intake.

Since no food products with added lycopene as a colour were found on the Belgian market, the reported intake represents the intake from natural sources only. The lack of an E160d number of lycopene on food labels is probably due to the fact that industry uses tomato-based powders or paste as addition instead of the additive.

To date, no recommended dietary intake levels have been established for lycopene. However, based on the established ADI value we can imply that no more than $35 \mathrm{mg}$ of lycopene $(0.5 \mathrm{mg} / \mathrm{kg}$ BW per $\mathrm{d} \times 70 \mathrm{~kg}$ average BW) should be ingested on a daily basis. Lycopene may have beneficial effects to health. One meta-analysis reported a protective effect of lycopene on serum cholesterol and blood pressure ${ }^{31)}$. The study on serum lipids revealed a significant cholesterol-lowering effect of lycopene for serum total cholesterol (mean change: -7.55 (se 6.15$) \mathrm{mg} / \mathrm{dl} ; P=0.02)$ and LDL cholesterol (mean change: $-10 \cdot 35$ (se $5 \cdot 64) \mathrm{mg} / \mathrm{dl}, P=0 \cdot 0003)$ in the subgroup of trials using lycopene dosages of $\geq 25 \mathrm{mg}$ daily, whereas subgroup meta-analysis of trials using lower lycopene dosages was not significant. Meta-analysis of the effect of lycopene on systolic blood pressure of all trials suggested a significant blood-pressure-reducing effect (mean systolic blood pressure change: $-5 \cdot 60$ (SE 5.26) $\mathrm{mmHg}, P=0 \cdot 04)$. In our study however, lycopene intakes were lower than the $25 \mathrm{mg} / \mathrm{d}$ for the whole distribution of intake. On the other hand, increasing evidence suggests that a single serving of tomatoes or tomato products ingested daily may contribute to protection from DNA damage. As DNA damage seems to be involved in the pathogenesis of prostate cancer, the regular ingestion of tomatoes or tomato products might reduce the risk of disease $^{(32)}$. Another study among 27261 US women suggested that consuming $\geq 10$ compared with $<1.5$ servings of tomato-based food products weekly results in clinically modest but significant improvements in total cholesterol, 
total cholesterol:HDL cholesterol ratio and glycated $\mathrm{Hb}$ (HbA1c) but not in other coronary biomarkers ${ }^{(33)}$.

Limitations of the current study include the fact that products were analysed as purchased instead of as consumed, which may have underestimated especially cis-lycopene intake. Many factors affect lycopene bioavailability and absorption such as food processing, the presence of fat and individual variability in absorption capacity. These were not taken into account in the present study. Another important aspect to consider is that any given food source may vary greatly in lycopene content, because of differences in cultivar, technological processing, domestic cooking, etc. This was also not taken into account. Many more analyses on lycopene concentration in foods would be needed and a probabilistic intake assessment would have to be performed to take into account variation in lycopene concentration within foods.

\section{Conclusions}

The results of the present study showed that the mean lycopene intake of the Belgian adult population was about $4 \cdot 1 \mathrm{mg} / \mathrm{d}$ or $0.059 \mathrm{mg} / \mathrm{kg} \mathrm{BW}$ per $\mathrm{d}$. This intake was comparable to the lycopene intake in neighbouring countries and was well below the ADI value established by the European Food Safety Authority. Tomatoes and tomato products together with ready-to-eat meals containing tomato sauces were the products contributing the most to the lycopene intake.

\section{Acknowledgements}

Sources of funding: The authors acknowledge the financial support of the Federal Public Service of Health, Food Chain Safety and Environment. Conflicts of interest: The authors declare that they do not have any conflict of interest with regard to this study. Authors' contributions: S.V. and T.C. wrote the paper and contributed equally. T.C. performed the laboratory analyses and S.V. performed the statistical analyses. All authors contributed to the design of the study and critically revised draft versions of the manuscript.

\section{References}

1. Yahia EM (2009) The contribution of fruit and vegetable consumption to human health. In Fruit and Vegetable Phytochemicals, pp. 3-52 [LA de la Rosa, E Alvarez-Parrilla and GA Gonzalez-Agu, editors]. Singapore: Wiley-Blackwell.

2. Roldan-Gutierrez JM \& Dolores Luque de Castro M (2007) Lycopene: the need for better methods for characterization and determination. Trends Analyt Chem 26, 163-170.

3. European Food Safety Authority (2005) Opinion of the Scientific Panel on Dietetic Products, Nutrition and Allergies on a request from the Commission related to an application on the use of a tocopherol-containing oil suspensions from Blakeslea trispora as a novel food ingredient. EFSA J 212, 1-29.

4. Clinton SK (1998) Lycopene: chemistry, biology, and implications for human health and disease. Nutr Rev 56, $35-51$.

5. Boileau TW, Boileau AC \& Erdman JW Jr (2002) Bioavailability of all-trans and cis-isomers of lycopene. Exp Biol Med (Maywood) 227, 914-919.

6. Di MP, Kaiser S \& Sies H (1989) Lycopene as the most efficient biological carotenoid singlet oxygen quencher. Arch Biochem Biophys 274, 532-538.

7. Mordente A, Guantario B, Meucci E et al. (2011) Lycopene and cardiovascular diseases: an update. Curr Med Chem 18, 1146-1163.

8. Story EN, Kopec RE, Schwartz SJ et al. (2010) An update on the health effects of tomato lycopene. Annu Rev Food Sci Technol 1, 189-210.

9. Lu R, Dan H, Wu R et al. (2011) Lycopene: features and potential significance in the oral cancer and precancerous lesions. J Oral Pathol Med 40, 361-368.

10. Schroder FH, Hugosson J, Roobol MJ et al. (2009) Screening and prostate-cancer mortality in a randomized European study. N Engl J Med 360, 1320-1328.

11. Barber NJ \& Barber J (2002) Lycopene and prostate cancer. Prostate Cancer Prostatic Dis 5, 6-12.

12. Kirsh VA, Mayne ST, Peters U et al. (2006) A prospective study of lycopene and tomato product intake and risk of prostate cancer. Cancer Epidemiol Biomarkers Prev 15, 92-98.

13. Ilic D \& Misso M (2012) Lycopene for the prevention and treatment of benign prostatic hyperplasia and prostate cancer: a systematic review. Maturitas 72, 269-276.

14. Rao AV \& Rao LG (2007) Carotenoids and human health. Pharmacol Res 55, 207-216.

15. Garcia-Closas R, Berenguer A, Jose TM et al. (2004) Dietary sources of vitamin C, vitamin E and specific carotenoids in Spain. BrJ Nutr 91, 1005-1011.

16. Unlu NZ, Bohn T, Francis DM et al. (2007) Lycopene from heat-induced cis-isomer-rich tomato sauce is more bioavailable than from all-trans-rich tomato sauce in human subjects. BrJ Nutr 98, 140-146.

17. Gartner C, Stahl W \& Sies H (1997) Lycopene is more bioavailable from tomato paste than from fresh tomatoes. Am J Clin Nutr 66, 116-122.

18. Agarwal S \& Rao AV (2000) Tomato lycopene and its role in human health and chronic diseases. CMAJ 163, 739-744.

19. European Food Safety Authority (2010) Revised exposure assessment for lycopene as a food colour. EFSA J 8, 1444.

20. De Vriese S, Debacker G, de Henauw S et al. (2005) The Belgian food consumption survey: aims, design and methods. Arch Public Health 63, 1-16.

21. European Community (1994) European Parliament and Council Directive 94/36/EC of 30 June 1994 on colours for use in foodstuffs. Official Journal of The European Union 10.9.94, L237, 13-29.

22. Cucu T, Huvaere K, Van Den Berghe MA et al. (2012) A simple and fast HPLC method to determine lycopene in foods. Food Anal Methods 5, 1221-1228.

23. Slimani N \& Valsta L (2002) Perspectives of using the EPIC-SOFT programme in the context of pan-European nutritional monitoring surveys: methodological and practical implications. Eur J Clin Nutr 56, Suppl. 2, S63-S74.

24. Nusser SM, Carriquiry AL, Dodd KW et al. (1996) A semiparametric transformation approach to estimating usual daily intake distributions. J Am Stat Assoc 91, 1440-1449.

25. Iowa State University (1996) A User's Guide to C-SIDE. Software for Intake Distribution Estimation. Technical Report no. 96-TR 31. Ames, IA: Department of Statistics 
and Center for Agricultural and Rural Development, Iowa State University.

26. Krebs-Smith SM, Kott PS \& Guenther PM (1989) Mean proportion and population proportion: two answers to the same question? J Am Diet Assoc 89, 671-676.

27. Porrini M \& Riso P (2005) What are typical lycopene intakes? J Nutr 135, issue 8, 2042S-2045S.

28. VandenLangenberg GM, Brady WE, Nebeling LC et al. (1996) Influence of using different sources of carotenoid data in epidemiologic studies. J Am Diet Assoc 96, $1271-1275$.

29. Yong LC, Forman MR, Beecher GR et al. (1994) Relationship between dietary intake and plasma concentrations of carotenoids in premenopausal women: application of the USDA-NCI carotenoid food-composition database. Am J Clin Nutr 60, 223-230.
30. Carroll YL, Corridan BM \& Morrissey PA (1999) Carotenoids in young and elderly healthy humans: dietary intakes, biochemical status and diet-plasma relationships. Eur J Clin Nutr 53, 644-653.

31. Ried K \& Fakler P (2011) Protective effect of lycopene on serum cholesterol and blood pressure: meta-analyses of intervention trials. Maturitas 68, 299-310.

32. Ellinger S, Ellinger J \& Stehle P (2006) Tomatoes, tomato products and lycopene in the prevention and treatment of prostate cancer: do we have the evidence from intervention studies? Curr Opin Clin Nutr Metab Care 9, $722-727$.

33. Sesso HD, Wang L, Ridker PM et al. (2012) Tomato-based food products are related to clinically modest improvements in selected coronary biomarkers in women. $J$ Nutr 142, 326-333. 